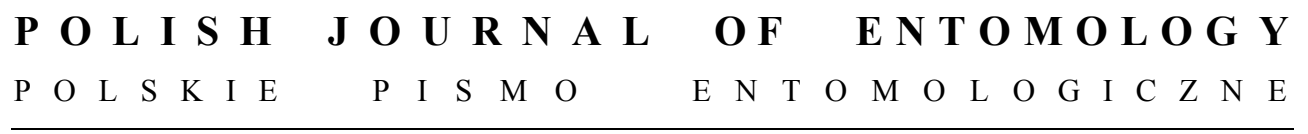

VOL. 81: $305-310$

Gdańsk

31 December 2012

DOI: $10.2478 / \mathrm{v} 10200-012-0010-2$

\title{
Records of phoretic mesostigmatid mites (Acari: Mesostigmata) on beetles (Coleoptera: Carabidae, Cerambycidae, Elateridae, Erotylidae, Scolytinae) in the Białowieża Primeval Forest
}

\author{
DARIUSZ J. GWIAZDOWICZ ${ }^{1}$, JERZY M. GUTOWSKI ${ }^{2}$ \\ ${ }^{1}$ Poznań University of Life Sciences, Department of Forest Protection, \\ Wojska Polskiego 71c, 60-625 Poznań, Poland, e-mail: dagwiazd@up.poznan.pl; \\ ${ }^{2}$ Forest Research Institute, European Centre for Natural Forests, \\ 17-230 Białowieża, Poland, e-mail: jgutowski@las.ibl.bialowieza.pl; \\ ${ }^{2}$ Białystok University of Technology, Faculty of Forestry, Piłsudskiego 8, \\ 17-200 Hajnówka, Poland
}

\begin{abstract}
Nine species of phoretic mesostigmatid mites are recorded on twelve species of beetles (Coleoptera: Carabidae, Cerambycidae, Elateridae, Erotylidae, Scolytinae). The most numerous species of insects on which mites were found were Carabus granulatus (91 specimens of mites) and Plagionotus detritus (67). The most numerous mites were Iphidosoma fimetarium (100 specimens) and Trichouropoda sociata (77).
\end{abstract}

KEY WORDS: Gamasina, Uropodina, phoresy, Białowieża Primeval Forest.

\section{INTRODUCTION}

Mites of the order Mesostigmata inhabit many microhabitats such as leaf litter, moss, decaying wood, nests of birds and mammals, and also excrement and carcasses. They are also numerous in bark beetle galleries or ant nests (GWIAZDOWICZ 2008a, b). Due to the small body size and in consequence, the limited opportunities for dispersal, many species from this group of mites have a strong phoretic relationship with insects. Using selected species of insects as a carrier, some mesostigmatid mites colonize new areas and new microhabitats (BAJERLEIN \& BŁoszYK 2004, GWIAZDOWICZ \& COULSON 2010, GWIAZDOWICZ \& HAITLINGER 2010). 
Although these phoretic relationships between mites of the order Mesostigmata and insects have already been investigated by many authors (IGNATOWICZ 1974; CHMIELEWSKI 1977, 1983; HAITLINGER 1985, 1987, 1988, 1990, 1991, 2008; BAJERLEIN \& PRZEWOźNY 2005; BAJERLEIN 2011; GWIAZDOWICZ et al. 2011), there is still a considerable deficiency of knowledge. A thorough investigation of this phenomenon and of the rules and mechanisms governing this relationship, will enable the migration of mites and the means by which they colonize new microhabitats to be explained, thus leading to a better understanding of the mechanisms of succession.

The Białowieża Primeval Forest, recognized as one of the most natural ecosystems in Europe, was selected as the study site. Conducted in the Białowieża National Park by GWIAZDOWICZ (2000), the research focused on coprophagous and necrophagous insects of the genera Geotrupes, Nicrophorus and Silpha.

\section{Acknowledgements}

The study is financed by the grant NN 309070736 of the Ministry of Science.

\section{MATERIAL AND METHODS}

Beetles were caught in 2009-2011 in different localities in the Białowieża Primeval Forest, both within the Białowieża National Park (about 17\% of the Polish part of the Białowieża Primeval Forest) and in the managed part of the forest outside the National Park. Material was collected from May to October, a period when the air temperature was at least $5^{\circ} \mathrm{C}$. Most of the mites were caught in different kinds of traps [Moericke traps (yellow pan traps), Barber traps (pitfall traps), barrier traps (Netocia traps and cross-vane pan traps)]. Some were collected directly by hand, during a search in their feeding material - lying and standing dead trees. The beetles were minutely examined under a stereoscopic microscope and identified. Specimens with Acarina deutonymphs attached were taken for this study.

All the insects collected were immersed in $70 \%$ ethanol. Later, permanent (using Hoyer's medium) or semi-permanent (using lactic acid) slide preparations of the mites were made; these were counted and then identified using the taxonomical literature.

\section{RESULTS}

The mesostigmatid mites found are listed below in systematic order together with information on their hosts, and brief literature information on their preferred habitats. 


\section{Microgynium rectangulatum TRÄGÅRDH, 1942}

Host: Elateridae: Lacon lepidopterus (PANZER).

One phoretic deutonymph was found on one specimen of Lacon lepidopterus.

Ecology: most frequently reported from rotting wood, bark beetle galleries, leaf litter, among tree roots and from rodent nests (GWIAZDOWICZ 2010).

\section{Iphidosoma fimetarium (J. MÜLLER, 1859)}

Host: Carabidae: Carabus granulatus L., Carabus cancellatus ILLIGER.

78 deutonymphs were found on one specimen of Carabus granulatus and 13 deutonymphs on the other specimen of this species. However, 9 deutonymphs were found on a specimen of Carabus cancellatus.

Ecology: leaf litter, moss, between grass roots (KARG 1993); phoresy of insects such as Cerambycidae, Lygaeidae, and also on mammals (BREGETOVA 1977).

\section{Polyaspis sansonei BERLESE, 1916}

Host: Cerambycidae: Tetropium castaneum (L.).

Nine phoretic deutonymphs were found on one specimen of Tetropium castaneum.

Ecology: decaying wood (WIŚNIEWSKI \& HIRSCHMANN 1993).

\section{Trichouropoda obscura (C.L. KOCH, 1836)}

Host: Curculionidae: Hylastes angustatus (HERBST), Hylastes ater (PAYKULL).

One deutonymph was found on one specimen of Hylastes angustatus, and one deutonymph on Hylastes ater.

Ecology: decaying wood, hollows, in galleries of Scolytinae, and also on Nitidulidae and Pyrochroidae (WIŚNIEWSKI \& HIRSCHMANN 1993).

\section{Trichouropoda ovalis (C.L. KOCH, 1839)}

Host: Elateridae: Ampedus melanurus Mulsant et GuIlleBEAU, Ectinus aterrimus (L.), Tetropium castaneum (L.).

One deutonymph was found on Ampedus melanurus, two deutonymphs on Ectinus aterrimus, and one deutonymph on Tetropium castaneum.

Ecology: eurytopic species encountered in leaf litter, moss, fungi, decaying wood, hollows, and also on Cerambycidae, Scarabaeidae, Elateridae, Silphidae, Lucanidae, in nests of Formicidae, Scolytinae galleries, and also in nests of birds and mammals, for instance, Talpidae (WIŚNIEWSKI \& HIRSCHMANN 1993). 


\section{Trichouropoda polytricha (VITZTHUM, 1923)}

Host: Curculionidae: Ips typographus (L.).

16 deutonymphs were found on one specimen of Ips typographus.

Ecology: Scolytinae galleries, tree trunk remains (WIŚNIEWSKI \& HIRSCHMANN 1993).

\section{Trichouropoda sociata (VITZTHUM, 1923)}

Host: Cerambycidae: Plagionotus detritus (L.), Tetropium fuscum (FABRICIUS), Tetropium castaneum (L.).

44 deutonymphs were found on one specimen of Plagionotus detritus and 23 deutonymphs on the other. Moreover, 2 deutonymphs were found on one specimen of Tetropium fuscum and 3 deutonymphs on the other. 4, 1, 1 and 2 deutonymphs each were found on four specimens of Tetropium castaneum.

Ecology: Scolytinae galleries, phoresy on Cerambycidae, decaying wood, halophytes (WIŚNIEWSKI \& HIRSCHMANN 1993).

\section{Nenteria sp.}

Host: Erotylidae: Triplax russica (L.).

6 deutonymphs were found on one specimen of Triplax russica.

\section{Uroobovella ipidis (VITZTHUM, 1923)}

Host: Curculionidae: Ips typographus (L.), Cerambycidae: Tetropium castaneum (L.).

28 deutonymphs were found on one specimen of Ips typographus and 3 deutonymphs on another; one deutonymph was found on one specimen of Tetropium castaneum.

Ecology: in Scolytinae galleries and on specimens of Scolytinae (WIŚNIEWSKI \& HIRSCHMANN 1993).

\section{DISCUSSION}

Mesostigmatid mites found on 23 insects of 12 species were studied. The insect species are as follows: Ampedus melanurus (Elateridae), Carabus granulatus, C. cancellatus (Carabidae), Ectinus aterrimus (Elateridae), Hylastes angustatus, H. ater, Ips typographus (Curculionidae), Lacon lepidopterus (Elateridae), Plagionotus detritus, Tetropium fuscum, T. castaneum (Cerambycidae) and Triplax russica (Erotylidae). 250 specimens of mites representing 9 species were found on these insects. The largest number of mites, 78 specimens of Iphidosoma fimetarium, were found on one specimen of Carabus granulatus, and 44 specimens of Trichouropoda sociata on one Plagionotus detritus. 
The most numerous species in the collected material were Iphidosoma fimetarium (100 specimens) and Trichouropoda sociata (80), which are classified as superdominants. Following analysis of the constancy indicator, T. sociata was classified as an accessory species, and the remaining species were regarded as accidentals (Table).

Table. List of mesostigmatid mites occurring on insects.

\begin{tabular}{|l|c|c|c|c|}
\hline \multicolumn{1}{|c|}{ Species of mites } & $\begin{array}{c}\text { Number } \\
\text { of insects }\end{array}$ & $\begin{array}{c}\text { Number } \\
\text { of mites }\end{array}$ & $\begin{array}{c}\text { Dominance } \\
{[\%]}\end{array}$ & $\begin{array}{c}\text { Frequency } \\
\text { [\%] }\end{array}$ \\
\hline Iphidosoma fimetarium & 3 & 100 & 40.0 & 13.0 \\
\hline Microgynium rectangulatum & 1 & 1 & 0.4 & 4.4 \\
\hline Polyaspis sansonei & 1 & 9 & 3.6 & 4.4 \\
\hline Trichouropoda obscura & 2 & 2 & 0.8 & 8.6 \\
\hline Trichouropoda ovalis & 3 & 4 & 1.6 & 13.0 \\
\hline Trichouropoda polytricha & 1 & 16 & 6.4 & 4.4 \\
\hline Trichouropoda sociata & 8 & 80 & 32 & 34.8 \\
\hline Nenteria sp. & 1 & 6 & 2,4 & 4.4 \\
\hline Uroobovella ipidis & 3 & 32 & 12.8 & 13.0 \\
\hline Total & $\mathbf{2 3}$ & $\mathbf{2 5 0}$ & $\mathbf{1 0 0}$ & $\mathbf{1 0 0}$ \\
\hline
\end{tabular}

The mites under investigation were present only as deutonymphs, a typical phoretic form of the species found. The species of insects on which the largest numbers of mites were found were Carabus granulatus (91 mites), Plagionotus detritus (67) and Ips typographus (47). This is the first information on the phoretic relationship with mites for the following insects: Ampedus melanurus, Ectinus aterrimus, Hylastes angustatus, Lacon lepidopterus, Plagionotus detritus, Tetropium fuscum, T. castaneum and Triplax russica.

\section{REFERENCES}

BAJERLEIN D. 2011. Seasonal abundance and infestation of deutonymphs of Uropoda orbicularis (MüLLER, 1776) (Acari: Mesostigmata) phoretic on coprophilous beetles (Scarabaeidae, Geotrupidae, Aphodiidae, Hydrophilidae, Histeridae). International Journal of Acarology 37: 216-227.

BAJERLEIN D., BŁoSZYK J. 2004. Phoresy of Uropoda orbicularis (Acari: Mesostigmata) by beetles (Coleoptera) associated with cattle dung in Poland. European Journal of Entomology 101: 185-188.

BAJERLEIN D., PRZEWOźNY M. 2005. Coprophagous hydrophilid beetles (Coleoptera: Hydrophilidae) as carriers of phoretic deutonymphs of Uropoda orbicularis (Acari: Mesostigmata) in Poland. European Journal of Entomology 102: 119-122.

Bregetova N.G. 1977. Family Eviphididae Berlese, 1913. [In:] Gilyarov M.S. \& Bregetova N.G. (eds). Opredelitiel' obitayushchikh v pochve kleshchei (Mesostigmata), Nauka, Leningrad, pp.: 554-569. [In Russian]. 
CHMIELEwSKi W. 1977. Wyniki obserwacji powiązań roztoczy z owadami (Acari-Insecta). Polskie Pismo Entomologiczne 47: 49-78.

ChMielewsKi W. 1983. Przypadki występowania roztoczy na owadach. Zeszyty Problemowe Postępów Nauk Rolniczych 25: 179-188.

GwiAZDOwicz D.J. 2000. Mites (Acari, Gamasida) associated with insects in the Białowieża National Park. Acta Parasitologica 45: 43-47.

GwiAZDOwICZ D.J. 2008a. Mesostigmatid mites (Acari) associated with Scolytidae in Poland. [In:] GwiAzDowicz D.J. (ed.). Selected problems of acarological research in forests. Wydawnictwo Uniwersytetu Przyrodniczego, Poznań, pp.: 59-95.

GwiAZDOwicZ D.J. 2008b. Mesostigmatid mites (Acari) associated in nests of Formicidae in Poland. [In:] GwiAzDowicz D.J. (ed.). Selected problems of acarological research in forests. Wydawnictwo Uniwersytetu Przyrodniczego, Poznań, pp.: 97-112.

GwiAZDOwicz D.J., Coulson S.J. 2010. First record of Thinoseius spinosus (Acari, Eviphididae) from the High Arctic Island of Spitsbergen (Svalbard) including a key to deutonymphs of genus Thinoseius. International Journal of Acarology 36: 233-236.

Gwiazdowicz D.J., Haitlinger R. 2010. Antennoseius (Antennoseius) maltzevi and A. (A.) quadrispinosus n. sp. (Acari: Ascidae) associated with carabid beetles. Biologia, Bratislava 65: 99-103.

Gwiazdowicz D.J., KAMCZYC J., BŁoszyK J. 2011. The diversity of phoretic Mesostigmata of Ips typographus (Coleoptera: Scolytinae) caught in the Karkonosze forest. European Journal of Entomology 108: 489-491.

Haitlinger R. 1985. Roztocze (Acari: Podapolipidae, Parasitidae, Eviphididae, Macrochelidae, Ascidae) nowe lub rzadkie dla fauny Polski, zebrane z chrząszczy (Coleoptera) i gryzoni (Rodentia). Polskie Pismo Entomologiczne 55: 611-614.

HAitLinger R. 1987. Roztocze (Acari) nowe lub rzadkie w faunie Polski uzyskane z drobnych ssakow i owadów. Fragmenta Faunistica 30: 313-320.

HAitlinger R. 1988. Roztocze (Acari) występujące w Polsce na chrząszczach z rodzaju Carabus LinNAEUS, 1758 (Insecta, Coleoptera, Carabidae). Wiadomości Parazytologiczne 34: 329-346.

HAITLINGER R. 1990. Mites (Acari) occurring on Geotrupes vernalis (L., 1758) (Insecta, Scarabaeidae) in Poland. Wiadomości Parazytologiczne 36: 137-143.

HAITLINGER R. 1991. List of mites occurring on insects in Poland. Wiadomości Parazytologiczne 37: 85-90.

HAitLinger R. 2008. Mites associated with insects in Poland. [In:] GwiAZDOwicz D.J. (ed.). Selected problems of acarological research in forests. Wydawnictwo Uniwersytetu Przyrodniczego, Poznań, pp.: 113-125.

IgNatowicz S. 1974. Nowe dane o występowaniu roztoczy (Acarina) na owadach w Polsce. Polskie Pismo Entomologiczne 44: 705-713.

KARG W. 1993. Acari (Acarina), Milben Parasitiformes (Anactinochaeta), Cohors Gamasina LeACH. Raubmilben. Die Tierwelt Deutschlands, 59 Teil. Gustav Fischer Verlag, Jena, pp.: 1-523.

WiŚNIEWSKI J., HiRSCHMANN W. 1993. Katalog der Ganggattungen, Untergattungen, Gruppen und Arten der Uropodiden der Erde (Taxonomie, Literatur, Grösse, Verbreitung, Vorkommen). Acarologie 40: 1-220.

Received: March 9, 2012

Accepted: November 5, 2012 